\title{
The effects of vitamin $D$ and microfracture surgery technique on calcium and phosphorus: A pilot study
}

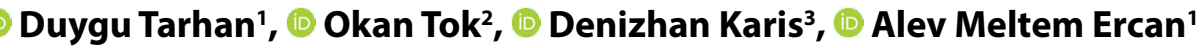

'Department of Biophysics, Cerrahpasa Medical Faculty, Istanbul University-Cerrahpasa, Istanbul, Turkey

${ }^{2}$ Department of Orthopedics and Traumatology, Acibadem Altunizade Hospital, Istanbul, Turkey

${ }^{3}$ Department of Biophysics, Medical Faculty, Istinye University, Istanbul, Turkey

\begin{abstract}
Objectives: Vitamin D has an important effect on calcium (Ca) and phosphorus (P) metabolism and bone health. It helps regulate the ratio of $\mathrm{Ca}$ and $\mathrm{P}$. The aim of this study was to investigate the effects of vitamin $\mathrm{D}$ and minor surgical stress on Ca and P levels in the liver, kidneys, and serum in 24 New Zealand rabbits with cartilage defects.

Methods: Experimental groups of MFS (only microfracture surgery), Vit D (only oral vitamin D supplementation), and MFS+Vit D (both microfracture surgery and oral vitamin D supplementation) were created. The levels of $C a$ and $P$ in serum, liver, and kidney samples were measured using a spectrophotometric method.

Results: The kidney $\mathrm{Ca} / \mathrm{P}$ ratio was lower and the serum $\mathrm{Ca} / \mathrm{P}$ ratio was higher in the MFS+Vit $\mathrm{D}$ groups than in the control group. The serum P level was significantly lower in the MFS and MFS+Vit D groups when compared with the control group. Conclusion: To the best of our knowledge, this is a novel study examining microfracture surgery and the effect on Ca and $\mathrm{P}$. The $\mathrm{Ca} / \mathrm{P}$ ratio revealed clinically valuable information about the important balance between $\mathrm{Ca} / \mathrm{P}$ ratio and the adequacy of vitamin D. Vitamin D supplementation before microfracture surgery may be beneficial and may prevent a de creased $\mathrm{Ca} / \mathrm{P}$ ratio due to the effect of surgical stress.
\end{abstract}

Keywords: Calcium, cartilage defects, microfracture surgery technique, phosphorus, rabbit, vitamin D

A rticular cartilage is hyaline cartilage and plays an important role as a highly specialized connective tissue [1, 2]. Its limited capacity for intrinsic healing and repair is related to the lack of blood vessels, nerves, and lymphatics [1-5]. In this regard, conservative or surgical treatments for cartilage damage aimed at the preservation of healthy articular cartilage are a significant issue in the practical applications of orthopedics and traumatology $[2,6]$. The microfracture surgery technique is a treatment for cartilage damage that was first introduced in 1999. This technique is actually a bone marrow stimulation method and a modification of a drilling method. An advantage of this method in comparison with drilling is that the subchondral bone undergoes less integrity loss due to the fact that the drilled holes are only $0.5-1 \mathrm{~mm}$ wide (vs $2-3 \mathrm{~mm}$ in the drilling method) [6-8].
Vitamin D has 2 forms, namely vitamin D2 and D3, both of which are fat-soluble and precursors for a group of hormones and sterols $[9,10]$. The most important effect of vitamin $D$ is on calcium ( $\mathrm{Ca}$ ) and phosphorus $(\mathrm{P})$ metabolism. Vitamin $\mathrm{D}_{3}$ influences the balance between $\mathrm{Ca}$ and $\mathrm{P}$ through its inverse relationship with the parathyroid hormone (PTH) [11, 12]. Calcitriol $\left[1.25(\mathrm{OH})_{2} D_{3}\right]$, the active form of vitamin $D_{3}$, plays an important role in the regulation of PTH gene activity. The liver and the kidneys have significant roles in the peripheral metabolism of PTH and in the production of vitamin D. It has been established that the liver also plays an important part in Ca metabolism and the expression of vitamin D [13].

The aim of this study was to investigate the effects of vitamin $\mathrm{D}$ and minor surgical stress on $\mathrm{Ca}$ and $\mathrm{P}$ elements in the liver, kidneys, and serum of rabbits with cartilage defects.

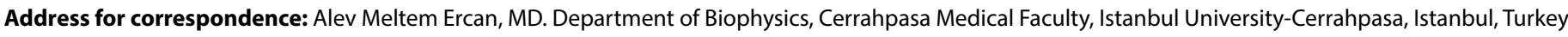
Phone: +90 2124143069 E-mail: ameltemercan@hotmail.com ORCID: 0000-0002-4533-4907

Submitted Date: July 22, 2019 Accepted Date: November 18, 2019 Available Online Date: January 31, 2020

${ }^{\circ}$ Copyright 2020 by International Journal of Medical Biochemistry - Available online at www.internationalbiochemistry.com

OPEN ACCESS This work is licensed under a Creative Commons Attribution-NonCommercial 4.0 International License. 


\section{Materials and Methods}

\section{Subjects}

In this study, 24 18-month-old New Zealand rabbits were divided into 4 groups according to treatment method. Standard articular cartilage damage in the medial femoral condyle of the right knee was created in all of the rabbits. The control group consisted of rabbits that underwent only cartilage damage $(n=6)$. The experimental groups were MFS (only microfracture surgery; $n=6$ ), Vit $D$ (only oral vitamin $D$ supplementation; $n=6$ ), and MFS+Vit $D$ (both microfracture surgery and oral vitamin $D$ supplementation; $n=6$ ). A description of the groups is provided in Table 1. The rabbits in the Vit $D$ and the MFS+Vit D groups were administered a daily oral dose of $1000 \mathrm{IU} / \mathrm{kg}$ vitamin $\mathrm{D}$ for 16 weeks. The microfracture surgery technique was only applied to the MFS and MFS+Vit D groups.

\section{Surgery technique}

After the right knee region was shaved, the rabbits were sedated using a mixture of intramuscular ketamine $\mathrm{HCl}$ (Ketalar, $50 \mathrm{mg} / \mathrm{mL}$; Pfizer Inc., NY, NY, USA) (35 mg/kg) and xylazine $\mathrm{HCl}$ (Rompun, 2\%, 25 mL; Bayer AG, Leverkusen, Germany) (10 mg/ $\mathrm{kg}$ ). The surgical site was sterilized using $10 \%$ polyvinyl-iodine (Batticon; Adeka llac, Istanbul, Turkey). The medial parapatellar arthrotomy and the right knee joint were accessed after a longitudinal incision approximately $5 \mathrm{~cm}$ in size was made beginning at the anterior right knee. The prepatellar fat pad was cleaned and sufficient visibility was established. Full-layer articular cartilage damage was created using a standard scalpel ( $4 \mathrm{~mm}$ diameter and $0.3 \mathrm{~mm}$ thickness) [14] and the subchondral cartilage in the load-bearing region of the medial femoral condyle articular cartilage was preserved. Four microfracture applications [8] were performed on the rabbits in the MFS and the MFS+Vit D groups using an $0.8 \mathrm{~mm}$ Kirschner wire according to a standardized template. The operation site was closed in accordance with the anatomy using 3.0 absorbable (Vycril; Ethicon Inc., Somerville, NJ, USA) and 3.0 non-absorbable sutures (Prolene; Ethicon Inc., Somerville, NJ, USA). The rabbits

\section{Table 1. General description of the study groups}

\begin{tabular}{|c|c|c|}
\hline Group & Experimental application & Number and sex \\
\hline \multirow[t]{2}{*}{ Control } & Control group & 2 male, 4 female $(n=6)$ \\
\hline & Cartilage defects & \\
\hline \multirow[t]{2}{*}{ MFS } & Cartilage defects & 5 male, 1 female $(n=6)$ \\
\hline & Microfracture surgery & \\
\hline \multirow[t]{2}{*}{ Vit D } & Cartilage defects & 6 male $(n=6)$ \\
\hline & Vitamin D $(1000 \mathrm{IU} / \mathrm{kg})^{*}$ & \\
\hline \multirow[t]{3}{*}{ MFS+Vit D } & Cartilage defects & 6 male $(n=6)$ \\
\hline & Microfracture surgery & \\
\hline & Vitamin D $(1000 \mathrm{IU} / \mathrm{kg})^{*}$ & \\
\hline
\end{tabular}

*Oral vitamin D 1000IU/kg daily, cholecalciferol, Devit-3 Oral Drop (DEVA, Istanbul, Turkey). MFS: Microfracture surgery; MFS+Vit D: Microfracture technique and vitamin D supplementation; Vit D: Vitamin D supplementation. were subsequently released for mobilization. No splinting was applied. Oral tramadol HCl (Contramal; Abdi Ibrahim Ilac, Istanbul, Turkey) (2-4 mg/kg) was administered to provide postoperative analgesia.

\section{Materials and methods}

Serum, liver, and kidney samples obtained from the study were stored in a deep freezer at $-80^{\circ} \mathrm{C}$ until evaluation. The serum samples were prepared for element measurement by creating a 1:10 dilution with distilled water. Liver and kidney samples were placed into tared tubes, weighed using a precision scale, and the weight of each sample was recorded. One $\mathrm{mL}$ nitric acid $\left(\mathrm{HNO}_{3}\right)$ was added to the tissue samples in a heat-resistant graduated tube and the samples were placed in a $200^{\circ} \mathrm{C}$ drying oven and left to dissolve. The tissue samples and the $\mathrm{HNO}_{3}$ mixture were allowed to cool at room temperature, and then $1 \mathrm{~mL}$ perchloric acid $\left(\mathrm{HClO}_{4}\right)$ was added and the mixtures were returned to the oven at $200^{\circ} \mathrm{C}$. The compound was subjected to wet ashing in the oven, distilled water was added to reach a total volume of $10 \mathrm{~mL}$, and the compound was vortexed. The samples were vortexed a second time and prepared for element analysis in the inductively coupled plasma-optical emission spectrophotometer (ICP-OES, Thermo iCAP 6000 series; Thermo Fisher Scientific, Inc., Waltham, MA, USA).

The element analysis of serum, liver, and kidney samples was performed using an ICP-OES device at the trace element analysis laboratory of the biophysics department of Cerrahpasa Medical Faculty. Wavelengths of $317.933 \mathrm{~nm}$ and $177.495 \mathrm{~nm}$ were used for the analysis of $\mathrm{Ca}$ and $\mathrm{P}$ elements, respectively. Stock solutions were prepared from standard solutions containing $\mathrm{Ca}$ and $\mathrm{P}$ and distilled water was used as a blank solution. The calibration graph was obtained from the ICP-OES device using blank and standard solutions and the element concentration measurements of the prepared serum samples were calculated. The results of serum element levels were expressed in micrograms per mililitre $(\mathrm{ppm}=\mu \mathrm{g} / \mathrm{mL})$. The results of kidney and liver element levels were given in micrograms per tissue gram $\left(\mu \mathrm{g} / \mathrm{g}_{\text {tissue }}\right)$.

\section{Statistical analysis}

Statistical analysis was performed with the statistical analysis software package IBM SPSS Statistics for Windows, Version 21.0 (IBM Corp, Armonk, NY, USA). All of the data were expressed as mean $\pm S D$. A value of $p<0.05$ was considered statistically significant. The Shapiro-Wilk test was applied to evaluate normality. One-way analysis of variance and the Kruskal-Wallis test were used to compare parametric and nonparametric groups, respectively.

\section{Results}

The $\mathrm{Ca} / \mathrm{P}$ ratio values and the levels of $\mathrm{Ca}$ and $\mathrm{P}$ in the liver, kidney and serum samples of all of the groups are provided in 


\begin{tabular}{lllll}
\multicolumn{4}{l}{ Table 2. The values of $\mathbf{C a}$ and $\mathbf{P}$ and the $\mathbf{C a} / \mathbf{P}$ ratio in liver, kidney, and serum samples of the groups } \\
\hline Calcium & Control & MFS & Vit D & MFS+Vit D \\
\hline Liver $\left(\mu \mathrm{g} / \mathrm{g}_{\text {tissue }}\right)$ & $136.7 \pm 34.2$ & $87.8 \pm 16$ & $91.9 \pm 19.2$ & $97 \pm 16$ \\
Kidney $\left(\mu \mathrm{g} / \mathrm{g}_{\text {tissue }}\right)$ & $175.9 \pm 43.5$ & $128.5 \pm 29.7$ & $161.4 \pm 52$ & $134.6 \pm 46.1$ \\
Serum $(\mu \mathrm{g} / \mathrm{mL})$ & $142 \pm 3.16$ & $136.6 \pm 2.24$ & $147.40 \pm 6.02$ & $141.50 \pm 8.52$ \\
Phosphorus & Control & MFS & Vit D & MFS+Vit D \\
\hline Liver $\left(\mu \mathrm{g} / \mathrm{g}_{\text {tissue }}\right)$ & $2446.8 \pm 284.2$ & $3096.2 \pm 164.7^{*}$ & $2429.7 \pm 206.2^{\text {aa }}$ & $2576.5 \pm 176^{\mathrm{b}}$ \\
Kidney $\left(\mu \mathrm{g} / \mathrm{g}_{\text {tissue }}\right)$ & $1862.5 \pm 166.1$ & $2184.4 \pm 376.6$ & $2068.3 \pm 547.6$ & $2250.7 \pm 368$ \\
Serum $(\mu \mathrm{g} / \mathrm{mL})$ & $84.8 \pm 7.19$ & $67.25 \pm 3.38^{* *}$ & $72.37 \pm 4.05$ & $65.76 \pm 9.20^{* *}$ \\
Ca/P ratio & Control & MFS & Vit D & MFS+Vit D \\
\hline Liver & $0.055 \pm 0.016$ & $0.028 \pm 0.005$ & $0.038 \pm 0.007$ & $0.038 \pm 0.006$ \\
Kidney & $0.096 \pm 0.021$ & $0.062 \pm 0.021$ & $0.079 \pm 0.014$ & $0.059 \pm 0.016^{*}$ \\
Serum & $1.688 \pm 0.167$ & $2.036 \pm 0.102$ & $2.043 \pm 0.139$ & $2.201 \pm 0.360^{*}$ \\
\hline
\end{tabular}

Data presented as mean $\pm S D$. *Control vs MFS, Vit D, and MFS+Vit $D,{ }^{*} p<0.05,{ }^{* *} p<0.01$. (a) MFS vs Vit D, (b) MFS vs MFS+Vit D. a, b: $p<0.05$; aa bb: $p<0.01$ ( $p<0.05$ statistically significant). Ca: Calcium; MFS: Microfracture surgery; MFS+Vit D: Microfracture technique and vitamin D supplementation; P: Phosphorus; Vit D: Vitamin D supplementation.

Table 2. There were no statistically significant differences between groups in the level of Ca. The serum P level, however, was significantly lower in the MFS and MFS+Vit D groups compared with the control group $(p<0.01)$. The level of $P$ in the liver was significantly higher in the MFS group compared with the control group $(p<0.05)$. The level of $P$ in the liver in the MFS group was higher than that of the Vit $D$ group $(p<0.01)$ and the MFS+Vit D group $(p<0.05)$. There was no statistically significant difference in the level of $P$ in the kidney. The kidney $\mathrm{Ca} / \mathrm{P}$ ratio was significantly lower and the serum $\mathrm{Ca} / \mathrm{P}$ ratio was significantly higher in the MFS+Vit D group compared with the control group $(p<0.05)$. Although the liver $\mathrm{Ca} / \mathrm{P}$ ratio in all groups was lower compared with the control group, there was no statistically significant difference between them.

\section{Discussion}

Cartilage tissue, a connective tissue originating from the mesodermal layer, degenerates due to factors such as age, trauma, or physical activity. Physical injuries to cartilage tissue are usually untreatable as a result of its avascular structure, the low metabolic activity of cells, the lack of lymphatic circulation, and nerve innervation. Osteoarthritis caused by cartilage defects causes pain and leads to limitation of movement, which has a negative effect on quality of life. Although the presence of vitamin $D$ receptors in the cartilage tissue of patients with osteoarthritis [15] and the protective effect of vitamin D on the progression of osteoarthritis [16] have been studied, such research is usually at the molecular level [17-19] and its relationship with trace elements and minerals in tissue has not been fully examined. The aim of this study was to assess the effects of minor surgical stress and vitamin $D$ on $\mathrm{Ca}$ and $\mathrm{P}$ elements in the liver, kidneys, and serum in rabbits with cartilage defects created using the microfracture surgery technique. According to our results, there was no statistically significant difference between groups in the liver, kidney, and serum Ca levels. The liver and kidney Ca levels in the MFS, Vit $D$, and MFS+Vit D groups were mathematically lower than the control group with no statistical significance. The serum Ca level of the Vit D and MFS+Vit D groups was higher than that of the MFS and control groups. Rabbits in the Vit D and MFS+Vit D groups were supplemented with vitamin D. It has been established that an increase in vitamin $D$ leads to a decrease in PTH. This decrease in PTH diminishes $\mathrm{Ca}$ excretion from the kidneys and accelerates the dissolution rate of $\mathrm{Ca}$ from bones, resulting in an increased $\mathrm{Ca}$ level in the extracelIular matrix [13]. This may explain the elevated serum Ca levels in the groups supplemented with Vitamin D.

Starr et al. [20] observed in a study of 23 patients that the urinary $\mathrm{Ca}$ and $\mathrm{P}$ levels decreased after surgery. It has been accepted that microfracture surgery can be an effective treatment, but it may cause surgical stress. Our study revealed out that the serum $P$ levels decreased, while $P$ levels in the both the liver and kidneys increased after microfracture surgery. The effect of PTH on the kidney decreased the concentration of $P$ in the extracellular matrix $[13,21]$. Surgical stress may lead to an increased PTH level. Therefore, increased absorption of $P$ in the liver and kidney tissues after surgery might be an effect of surgical stress.

Vitamin $D$ has an important role in Ca and $P$ metabolism. Several studies have demonstrated that a low vitamin $D$ concentration in the body affects the absorption of $\mathrm{Ca}$ and $\mathrm{P}$ and leads to decreased serum Ca and P levels. Vitamin D also helps to maintain the normal balance between the levels of $\mathrm{Ca}$ and P. Tzaphlidou and Zaichick [22] indicated in their study that the $\mathrm{Ca} / \mathrm{P}$ ratio may be more useful than the concentrations of $\mathrm{Ca}$ and $\mathrm{P}$ in the diagnosis of bone disorders.

According to our study results, the serum $\mathrm{Ca} / \mathrm{P}$ ratio in the control group was the lowest among the study groups. The serum $\mathrm{Ca} / \mathrm{P}$ ratio values were higher in the MFS+Vit D group 
compared with the MFS and Vit D groups, suggesting that vitamin $D$ supplementation accompanied by the microfracture technique had a positive effect on the $\mathrm{Ca} / \mathrm{P}$ ratio. The effect of surgical stress due to microfracture surgery reduced the $\mathrm{Ca} / \mathrm{P}$ ratio values in both the kidneys and the liver. Our study results indicated that there was no statistically significant difference in the $\mathrm{Ca}$ and $\mathrm{P}$ levels of the kidney between groups, though the MFS+Vit D group had a statistically lower $\mathrm{Ca} / \mathrm{P}$ ratio compared with the control group. Thus, the $\mathrm{Ca} / \mathrm{P}$ ratio may be clinically more significant than $\mathrm{Ca}$ and $\mathrm{P}$ values.

In conclusion, the $\mathrm{Ca} / \mathrm{P}$ ratio reflects the important balance between these 2 elements and the adequacy of vitamin $D$. Although the concentrations of $\mathrm{Ca}$ and $\mathrm{P}$ are important in healthy individuals, the $\mathrm{Ca} / \mathrm{P}$ ratio may be more useful than the concentration measurements in vitamin $D$ deficiency. Surgical stress decreases the $\mathrm{Ca} / \mathrm{P}$ ratio in both the liver and the kidneys. Therefore, vitamin $\mathrm{D}$ supplementation before microfracture surgery may be beneficial and prevent a decreased $\mathrm{Ca} / \mathrm{P}$ ratio due to the effect of surgical stress.

\section{Limitations}

The lack of the vitamin D and PTH measurements before and after surgery, and the relatively small number of rabbits and sex difference among the subjects are limitations to our study. Vitamin D and PTH measurements would be helpful to explain the mechanism. Additional studies with a larger number of subjects are needed.

Acknowledgement: This study was presented as an oral presentation in June 2017 at the 16th International Symposium of Trace Elements in Man and Animals (TEMA16), in Saint Petersburg, Russia.

Conflict of interest: The authors declare no conflict of interest.

Ethics Committee Approval: This study was approved by the Experimental Animal Research Implementation and Ethics Committee at Istanbul University on 25.02.2015 (No: 2016/20).

Financial Disclosure: This research did not receive any specific grant from funding agencies in the public, commercial, or not-forprofit sectors.

Peer-review: Externally peer-reviewed.

Authorship contributions: Concept - D.T., O.T., D.K., A.M.E.; Design - D.T., O.T., D.K., A.M.E.; Supervision - D.T., O.T., D.K., A.M.E.; Funding - None; Data collection \&/or processing - D.T., O.T., D.K., A.M.E.; Analysis and/or interpretation - D.T., D.K., A.M.E.; Literature search - D.T., O.T., D.K., A.M.E.; Writing - D.T., O.T., D.K., A.M.E.; Critical review - D.T., O.T., D.K., A.M.E.

\section{References}

1. Grande DA, Schwartz JA, Brandel E, Chahine NO, Sgaglione N. Articular cartilage repair: where we have been, where we are now, and where we are headed. Cartilage 2013;4:281-5.
2. Alford JW, BJ Cole BJ. Cartilage restoration, part I: basic science, historical perspective, patient evaluation and treatment options. Am J Sports Med 2005;33:295-306.

3. Buckwalter JA, Mankin HJ. Articular cartilage, part 1: tissue design and chondrocyte-matrix interaction. Instr Course Lect 1998;47:477-86.

4. Luo Y, Sinkeviciute D, He Y, Karsdal M, Henrotin Y, Mobasheri $A$, et al. The minor collagens in articular cartilage. Protein Cell 2017;8:560-72.

5. Poole AR, Kojima T, Yasuda T, Mwale F, Kobayashi M, Laverty S. Composition and structure of articular cartilage: a template for tissue repair. Clin Orthop Relat Res 2001;S26-33.

6. Hunziker EB. Articular cartilage repair: basic science and clinical progress. A review of the current status and prospects. Osteoarthritis Cartilage 2002;10:432-63.

7. O'Driscoll SW. Current concepts review-the healing and regeneration of articular cartilage. J Bone Joint Surg Am 1998;80:1795-812.

8. Bedi A, Feeley BT, Williams RJ 3rd. Management of articular cartilage defects of the knee. J Bone Joint Surg Am 2010;92:9941009.

9. Iglar PJ, Hogan KJ. Vitamin D status and surgical outcomes: a systematic review. Patient Saf Surg 2015;9:14.

10. Calışkan Ozcelik D, Kocer H, Kasım I, Sencan I, Kahveci R, Ozkara A. Vitamin D. Turk Med J 2012;6:61-7.

11. Yavuz D, Mete $T$, Yavuz R, Altunoglu A. Vitamin D, calcium \& mineral metabolism, extraskeletal effects of vitamin $D$ and the use of nutritional vitamin $d$ in chronic kidney disease. Ankara Med J 2014;14:162-71.

12. Goretti Pinedo M, Alon US. Phosphate homeostasis and its role in bone health. Pediatr Nephrol 2017;32:1999.

13. Murray RK, Granner DK, Mayes PA, Rodwell VW. Harper's illustrated biochemistry. $26^{\text {th }}$ ed. New York: McGraw-Hill Companies; 2001.

14. Brown FH. Diet and husbandry. Textbook of rabbit medicine. $3^{\text {rd }}$ ed. Oxford: Butterworth-Heinemann, Elsevier Health Sciences; 2002.

15. Tetlow LC, Woolley DE. Expression of vitamin D receptors and matrix metalloproteinases in osteoarhritic cartilage and human articular chondrocytes in vitro. Osteoarthritis Cartilage 2001;9:423-31.

16. Castillo EC, Hernandez-Cueto MA, Vega-Lopez MA, Lavalle C, Kouri JB, Ortiz-Navarrete V. Effects of Vitamin D supplementation during the induction and progression of osteoarthritis in a rat model. Evid Based Complement Alternat Med 2012;2012:156563.

17. Boyan BD, Jennings EG, Wang L, Schwartz Z. Mechanisms regulating differential activation of membrane-mediated signaling by 1alpha,25(OH)2D3 and 24R,25(OH)2D3. J Steroid Biochem Mol Biol 2004;89-90:309-15.

18. Masuyama R, Stockmans I, Torrekens S, Van Looveren R, Maes $C$, Carmeliet $P$, et al. Vitamin $D$ receptor in chondrocytes promotes osteoclastogenesis and regulates FGF23 production in osteoblasts. J Clin Invest 2006;116:3150-9. 
19. Schwartz Z, Sylvia VL, Luna MH, DeVeau P, Whetstone R, Dean $\mathrm{DD}$, et al. The effect of $24 \mathrm{R}, 25-(\mathrm{OH})(2) \mathrm{D}(3)$ on protein kinase $\mathrm{C}$ activity in chondrocytes is mediated by phospholipase $\mathrm{D}$ whereas the effect of 1 alpha, $25(\mathrm{OH})(2) \mathrm{D}(3)$ is mediated by phospholipase C. Steroids 2001;66:683-94.

20. STARR KW, WYNNE KN, CHORLTON SH. Calcium and phosphorus metabolism after surgery. Nature 1958;182:1505-6.
21. Koshihara M, Masuyama R, Uehara M, Suzuki K. Effect of dietary calcium: Phosphorus ratio on bone mineralization and intestinal calcium absorption in ovariectomized rats. Biofactors 2004;22:39-42.

22. Tzaphlidou M, Zaichick V. Calcium, phosphorus, calcium-phosphorus ratio in rib bone of healthy humans. Biol Trace Elem Res 2003;93:63-74. 